\title{
ANALISIS PENGARUH STRUKTUR MODAL TERHADAP PROFITABILITAS PERUSAHAAN SEKTOR KONSUMSI YANG TERDAFTAR DI BURSA EFEK INDONESIA PERIODE 2014-2016
}

\author{
Christopher \\ Program Studi Magister Manajemen Universitas Tarumanagara \\ christ_toper94@yahoo.com
}

\begin{abstract}
The relationship between capital structure and profitability cannot be ignored because the improvement in the profitability is necessary for the long-term survivability of the firm. This paper seeks to investigate the relationship between capital structure and profitability of listed firms on the Indonesia Stock Exchange during a three-year period. A sample of 35 Indonesia firms listed on Indonesia Stock Exchange for a period of 3 years from 2014-2016 was selected. The correlations and regression analysis were used to estimate the functions relating to profitability (measured by return on equity) with measures of capital structure. Empirical results show a positive relationship between i) short-term debt to total assets and profitability and ii) total debt to total assets and profitability in the service industry, and negative relationship between long-term debt to total assets and profitability. This paper offers useful insights for the owners/operators, managers, and lending institutions based on empirical evidence, and suggests that profitable firms depend more on debt as their main financing option.
\end{abstract}

Keywords : Capital Structure, Short-term debt to total assets, Long-term debt to total assets, Total debts to total assets, Size, Sales Growth, Profitability, Return on Equity.

\section{PENDAHULUAN}

Tingginya permintaan konsumsi selama Ramadan, rupanya jadi berkah bagi emiten produsen ayam Tanah Air seperti PT Charoen Pokphand Indonesia (CPIN) dan PT Japfa Comfeed Indonesia (JPFA). Saat memasuki bulan puasa dan Lebaran, tingkat konsumsi masyarakat lebih tinggi dibanding hari biasa, terutama konsumsi bahan makanan, maka tidak heran kalau terjadi kenaikan harga. Analis Bahana Sekuritas Michael Setjoadi menilai, pada kuartal II-2018 sudah terjadi kenaikan harga ayam broiler. Kenaikan harga sepanjang Ramadan biasanya memberi kontribusi terbesar selama satu tahun, sekitar 31\% terhadap total profitabilitas kedua perusahaan ini sepanjang setahun.

Pada kuartal I-2018, Japfa telah meningkatkan produksi DOC lebih dari 20\%, sehingga mendukung kenaikan volume penjualan pakan sebesar $14,5 \%$ dan penjualan ayam pedaging yang naik 30\%. Sedangkan pesaingnya, Charoen hanya membukukan kenaikan volume penjualan pakan sebesar 4,2\%, dengan volume penjualan DOC naik 2,5\% pada kuartal I2018, dibanding periode yang sama tahun lalu. Kinerja positif yang dibukukan Japfa, tentunya berpengaruh terhadap penjualan selama Ramadhan ini dengan kenaikan produksi DOC yang telah dilakukan sejak kuartal I-2018. Bahana menilai kinerja kedua produsen ayam ini akan lebih baik dibanding tahun lalu akibat kenaikan permintaan dan harga selama Ramadan serta ketersediaan jagung lokal untuk pakan. Makanya, Bahana Sekuritas menaikkan proyeksi target harga dan perkiraan kinerja untuk Japfa dan Charoen 2018.

Pendapatan perusahaan berkode saham JPFA ini diperkirakan naik menjadi Rp 33,76 triliun pada akhir 2018. Prediksi ini lebih tinggi jika dibandingkan dengan sebelumnya Rp 32,1 triliun. Laba bersih diperkirakan akan naik menjadi $\mathrm{Rp}$ 1,6 triliun, dari perkiraan sebelumnya sebesar $\mathrm{Rp} 1,43$ triliun. Sedangkan untuk Charoen, Bahana Sekuritas merekomendasikan untuk tahan, dengan target harga Rp 3.580 per saham, naik dari target 
sebelumnya Rp 3.520 per saham. Bahana menilai, valuasi harga sudah kemahalan dan prospek kinerja tidak sebaik Japfa. Pendapatan perusahaan berkode saham CPIN ini diperkirakan turun menjadi Rp 54,44 triliun, dari perkiraan sebelumnya sebesar Rp 55,33 triliun. Namun, laba bersih diperkirakan naik menjadi Rp 3,46 triliun, dari perkiraan sebelumnya sebesar Rp 3,4 triliun.

Terjadinya pertumbuhan penjualan dan laba bersih pada perusahaan konsumsi tersebut mendorong peneliti untuk melakukan penelitian untuk mengungkapkan faktor-faktor yang mungkin mendorong profitabilitas mereka. Adapun faktor-faktor yang diuji dan dimasukkan ke dalam penelitian adalah struktur modal. Peneliti ingin melihat bagaimanakah struktur modal pada perusahaan-perusahaan konsumsi tersebut dan bagaimana dampaknya terhadap profitabilitas.

Keputusan struktur modal penting karena kebutuhan untuk memaksimalkan pengembalian perusahaan, dan karena dampaknya, keputusan tersebut mengenai kemampuan perusahaan untuk mengatasi lingkungan persaingannya. Struktur modal perusahaan adalah campuran sekuritas yang berbeda. Secara umum, perusahaan dapat memilih di antara banyak struktur modal alternatif. Misalnya, perusahaan dapat mengatur pembiayaan sewa guna usaha, menggunakan waran, menerbitkan obligasi konversi, kontrak masuk atau swap perdagangan. Perusahaan juga dapat mengeluarkan puluhan sekuritas yang berbeda dalam kombinasi yang tak terhitung jumlahnya untuk memaksimalkan nilai pasar secara keseluruhan (Abor, 2005, hal 438 sebagaimana dikutip dari Gill, Biger, dan Mathur, 2011).

Sejumlah teori telah maju dalam menjelaskan struktur permodalan perusahaan. Terlepas dari teori banding struktur modal, penelitian dalam manajemen keuangan belum dapat menemukan model untuk struktur modal yang optimal. Hal terbaik yang bisa dicapai akademisi dan praktisi adalah resep yang memenuhi tujuan jangka pendek (Abor, 2005, hal 438 sebagaimana dikutip dari Gill, Biger, dan Mathur, 2011). Kurangnya konsensus tentang apa yang akan memenuhi syarat sebagai struktur modal yang optimal dalam perusahaan industri sektor konsumsi memotivasi untuk melakukan penelitian ini. Pemahaman yang lebih baik mengenai isu-isu yang dihadapi memerlukan pandangan mengenai struktur modal dan pengaruhnya terhadap profitabilitas perusahaan.

Bedasarkan fenomena dan untuk pengembangan penelitian sebelumnya, maka peneliti bermaksud untuk melakukan penelitian dengan judul : "ANALISIS PENGARUH STRUKTUR MODAL TERHADAP PROFITABILITAS PERUSAHAAN SEKTOR KONSUMSI YANG TERDAFTAR DI BURSA EFEK INDONESIA PERIODE 2014-2016". Bedasarkan latar belakang di atas, maka tujuan yang ingin dicapai dalam penelitian ini adalah sebagai berikut :

- Untuk mengetahui apakah terdapat pengaruh yang signifikan dari hutang jangka pendek terhadap profitabilitas perusahaan sektor konsumsi yang terdaftar di Bursa Efek Indonesia periode 2014-2016.

- Untuk mengetahui apakah terdapat pengaruh yang signifikan dari hutang jangka panjang terhadap profitabilitas perusahaans sektor konsumsi yang terdaftar di Bursa Efek Indonesia periode 2014-2016.

- Untuk mengetahui apakah terdapat pengaruh yang signifikan dari hutang secara keseluruhan terhadap profitabilitas perusahaan sektor konsumsi yang terdaftar di Bursa Efek Indonesia periode 2014-2016.

\section{TELAAH PUSTAKA}

Definisi struktur modal menurut Lasher (2011 : 555) adalah "The mix of capital components in use by a company at a point in time is known as its capital structure. We generally describe capital structure in percentage terms referring to the relative sizes of the component." 
Sedangkan menurut Abor (2005) struktur modal didefinisikan sebagai campuran antara hutang dan ekuitas yang digunakan perusahaan dalam operasinya. Menurut Brealey dan Myers (sebagaimana yang dikutip dalam Abor, 2005), pilihan struktur modal pada dasarnya adalah masalah pemasaran. Mereka menyatakan bahwa perusahaan dapat mengeluarkan puluhan sekuritas yang berbeda dalam kombinasi yang tak terhitung jumlahnya, namun mencoba untuk menemukan kombinasi khusus yang memaksimalkan nilai pasar. Menurut Weston dan Brigham (sebagaimana yang dikutip dalam Abor, 2005), struktur modal yang optimal adalah yang memaksimalkan nilai pasar saham perusahaan yang beredar.

Modigliani dan Miller (sebagaimana yang dikutip dalam Abor, 2005) meninjau kembali posisi terdahulu dengan memasukkan manfaat pajak sebagai penentu struktur modal perusahaan. Fitur utama perpajakan adalah bunga adalah biaya yang dapat dikurangkan dari pajak. Sebuah perusahaan yang membayar pajak menerima sebagian bunga "perisai pajak" yang offset dalam bentuk pajak yang lebih rendah yang dibayarkan. Oleh karena itu, seperti yang diusulkan perusahaan harus menggunakan sebanyak mungkin modal hutang untuk memaksimalkan nilainya. Seiring dengan perpajakan perusahaan, para periset juga tertarik untuk menganalisis kasus pajak pribadi yang dikenakan pada individu. Miller (sebagaimana yang dikutip dalam Abor, 2005), berdasarkan peraturan pajak Amerika Serikat, membedakan tiga tarif pajak yang menentukan nilai total perusahaan. Ini adalah: (1) tarif pajak perusahaan; (2) tarif pajak yang dikenakan atas penghasilan dividen; Dan (3) tarif pajak yang dikenakan pada pendapatan bunga arus. Menurut Miller (sebagaimana yang dikutip dalam Abor, 2005), nilai perusahaan bergantung pada tingkat relatif setiap tarif pajak, dibandingkan dengan dua tingkat pajak lainnya.

Myers dan Majluf (sebagaimana yang dikutip dalam Abor, 2005), berpendapat bahwa perusahaan lebih memilih sumber internal untuk keuntungan eksternal yang mahal. Jadi, menurut hipotesis pecking order, perusahaan yang menguntungkan dan karena itu menghasilkan pendapatan yang tinggi diharapkan dapat menggunakan lebih sedikit modal hutang daripada laba yang tidak menghasilkan pendapatan tinggi. Beberapa peneliti telah menguji pengaruh keuntungan pada leverage perusahaan. Friend dan Lang (1988) serta Kester (1986) menemukan hubungan yang sangat negatif antara rasio proabilitas dan rasio hutang / aset. Rajan dan Zingales (1995) dan Wald (1999) juga memastikan korelasi negatif antara keuntungan dan leverage yang signifikan.

Fama dan French (sebagaimana yang dikutip dalam Abor, 2005), menganalisis hubungan antara pajak, keputusan pembiayaan, dan nilai perusahaan, menyimpulkan bahwa hutang tersebut tidak mengakui manfaat pajak. Selain itu, tingkat leverage yang tinggi menghasilkan masalah keagenan di kalangan pemegang saham dan kreditur yang memprediksi hubungan negatif antara leverage dan profitabilitas. Oleh karena itu, informasi negatif terkait hutang dan keuntungan menyamarkan manfaat pajak dari hutang. Booth dkk. (sebagaimana yang dikutip dalam Abor, 2005) mengembangkan sebuah studi yang mencoba menghubungkan struktur permodalan beberapa perusahaan di negara-negara dengan pasar keuangan yang sangat berbeda. Mereka menyimpulkan bahwa variabel yang mempengaruhi pemilihan struktur modal perusahaan serupa, meskipun ada perbedaan besar yang disajikan oleh pasar keuangan. Selain itu, mereka menyimpulkan bahwa keuntungan memiliki hubungan terbalik dengan tingkat hutang dan ukuran perusahaan. Graham (sebagaimana yang dikutip dalam Abor, 2005) menyimpulkan dalam karyanya bahwa perusahaan besar dan menguntungkan menunjukkan tingkat hutang yang rendah. Mesquita dan Lara (sebagaimana yang dikutip dalam Abor, 2005) menemukan dalam penelitian mereka bahwa hubungan antara tingkat pengembalian dan hutang menunjukkan hubungan negatif untuk pendanaan jangka panjang. Namun, mereka menemukan hubungan positif untuk pembiayaan jangka pendek dan ekuitas.

Hadlock dan James (sebagaimana yang dikutip dalam Abor, 2005) menyimpulkan bahwa perusahaan lebih memilih pembiayaan pinjaman (hutang) karena mereka mengantisipasi tingkat pengembalian yang lebih tinggi. Taub (sebagaimana yang dikutip dalam Abor, 2005) 
juga menemukan koefisien positif yang signifikan untuk empat ukuran keuntungan dalam regresi dari tindakan ini terhadap rasio hutang. Petersen dan Rajan (sebagaimana yang dikutip dalam Abor, 2005) mengidentifikasi asosiasi yang sama, namun untuk industri. Baker (1973), yang bekerja dengan model persamaan simultan, dan Nerlove (1968) juga menemukan jenis asosiasi yang sama untuk industri (Abor, 2005). Roden dan Lewellen (sebagaimana yang dikutip dalam Abor, 2005) menemukan hubungan positif yang signifikan antara profitabilitas dan total hutang sebagai persentase dari total paket pembiayaan pembelian dalam studi mereka mengenai pembelian leveraged. Champion (sebagaimana yang dikutip dalam Abor, 2005) mengemukakan bahwa penggunaan leverage adalah salah satu cara untuk meningkatkan kinerja suatu organisasi.

Menurut Sartono (2001 : 122) Profitabilitas adalah kemampuan perusahaan memperoleh laba dalam hubungannya dengan penjualan, total aktiva maupun modal sendiri. Teori profitabilitas menurut Brigham dan Houston (2004 : 40), mengatakan bahwa perusahaan dengan tingkat pengembalian yang tinggi atas investasi menggunakan hutang yang relative kecil. Tingkat pengembalian yang tinggi memungkinkan untuk membiayai sebagian besar kebutuhan pendanaan dengan dana yang dihasilkan secara internal. Profitabilitas perusahaan sangat tergantung pada efektivitas dan efisiensi dari penggunaan sumber daya perusahaan berupa aset dan modal, sehingga dalam mengukur profitabilitas perusahaan memperhitungkan pengembalian atas asset dan modal perusahaan. Semakin tinggi keuntungan yang diperoleh berarti semakin rendah kebutuhan dana eksternal (hutang) sehingga semakin rendah pula struktur modalnya.

Hubungan antara struktur modal dan profitabilitas tidak dapat diabaikan karena peningkatan profitabilitas diperlukan untuk kelangsungan hidup jangka panjang perusahaan. Karena pembayaran bunga atas hutang dikurangkan dari pajak, penambahan hutang dalam struktur modal akan meningkatkan profitabilitas perusahaan. Oleh karena itu, penting untuk menguji hubungan antara struktur modal dan profitabilitas perusahaan untuk membuat keputusan struktur modal yang baik (Gill, Biger, dan Mathur, 2011).

\section{METODOLOGI PENELITIAN}

Populasi dari objek penelitian ini adalah seluruh perusahaan sektor konsumsi yang terdaftar di Bursa Efek Indonesia selama periode 2014-2016. Pemilihan sampel dilakukan dengan menggunakan metode purposive sampling, yaitu metode dimana sampel yang diambil dari populasi harus memenuhi kriteria tertentu yang digunakan dalam penelitian ini. Kriteria tersebut adalah:

a. Perusahaan konsumsi yang tidak IPO atau delisting selama periode 2014-2016.

b. Perusahaan konsumsi yang memiliki satu tahun pembukuan tidak kurang atau lebih dari 12 bulan.

Berikut merupakan gambar kerangka hipotesis :

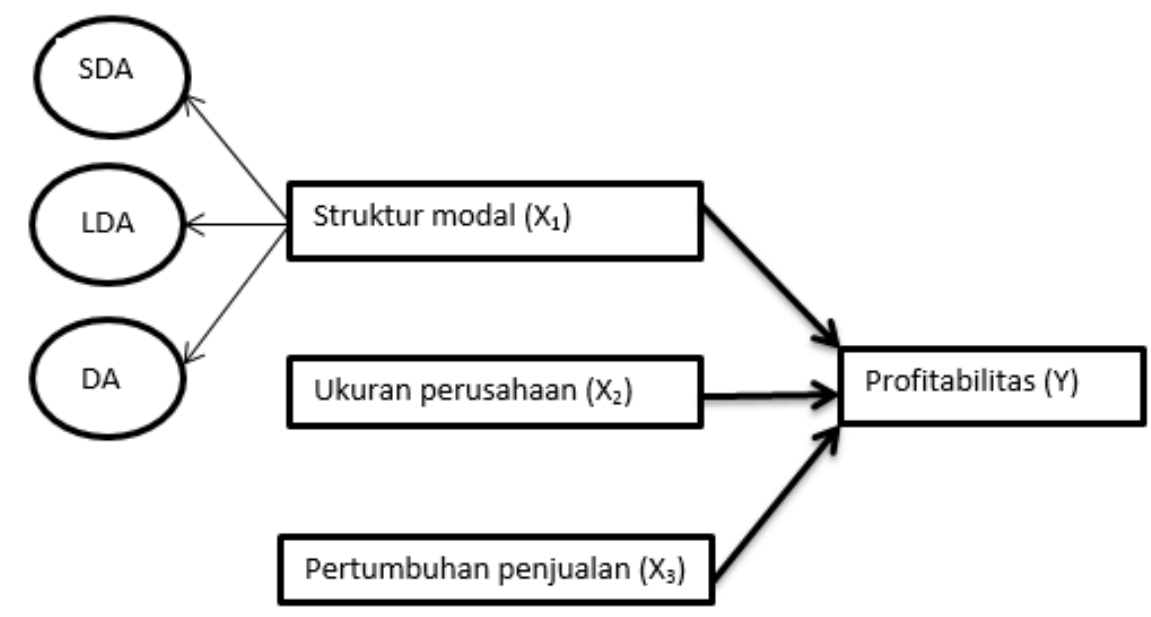


Sehingga skema tersebut dapat disusun menjadi 3 model penelitian yaitu :

- Profitability $_{\mathrm{i}, \mathrm{t}}=\mathrm{b}_{0}+\mathrm{b}_{1}{ }^{*}$ hutang jangka pendek $(\mathrm{SDA})+\mathrm{b}_{2} *$ ukuran perusahaan + $\mathrm{b}_{3} *$ pertumbuhan penjualan $+\mu_{\mathrm{i}, \mathrm{t}}$

- Profitability $y_{i, t}=b_{0}+b_{1} *$ hutang jangka panjang $(L D A)+b_{2} * u k u r a n$ perusahaan + $\mathrm{b}_{3} *$ pertumbuhan penjualan $+\mu_{\mathrm{i}, \mathrm{t}}$

- Profitability $\mathrm{i}_{\mathrm{i}, \mathrm{t}}=\mathrm{b}_{0}+\mathrm{b}_{1} *$ total hutang $(\mathrm{DA})+\mathrm{b}_{2} * \mathrm{ukuran}$ perusahaan $+\mathrm{b}_{3} *$ pertumbuhan penjualan $+\mu_{\mathrm{i}, \mathrm{t}}$

Oleh karena itu, dilakukan pengujian terhadap variabel-variabel di atas. Terdapat beberapa dugaan sementara, yaitu :

$\mathrm{H}_{1}$ : Hutang jangka pendek berpengaruh positif signifikan terhadap profitabilitas perusahaan.

$\mathrm{H}_{2}$ : Hutang jangka panjang berpengaruh positif signifikan terhadap profitabilitas perusahaan.

$\mathrm{H}_{3}$ : Total hutang berpengaruh positif signifikan terhadap profitabilitas perusahaan.

Data yang telah terkumpul diolah kembali dengan menggunakan bantuan program komputer, yaitu Statistical Product and Service Solution (SPSS) versi 23.0. Pengolahan data dimulai dari pengujian statistik deskriptif, uji asumsi klasik, dan pengujian hipotesis.

\section{ANALISIS DAN PEMBAHASAN}

Berikut dipaparkan statistik deskriptif dari variabel independen dan dependen dalam penelitian.

\section{Descriptive Statistics}

\begin{tabular}{|l|r|r|r|r|r|}
\hline & \multicolumn{1}{|c|}{$\mathrm{N}$} & \multicolumn{1}{c|}{ Minimum } & Maximum & \multicolumn{1}{c|}{ Mean } & Std. Deviation \\
\hline SDA & 87 &, 06433 &, 71213 &, 2832642 &, 15361793 \\
LDA & 87 &, 00229 &, 70370 &, 1331851 &, 12699513 \\
DA & 87 &, 06918 & 1,03326 &, 4164494 &, 19931785 \\
SIZE & 87 & 10,96251 & 13,94902 & 12,4592261 &, 75132140 \\
SG & 87 &, 00196 & 1,37346 &, 1487718 &, 20387066 \\
ROE & 87 &, 01674 & 3,17241 &, 3147568 &, 45549453 \\
Valid N (listwise) & 87 & & & & \\
\hline
\end{tabular}

Kemudian analisis regresi digunakan untuk menyelidiki hubungan antara struktur modal dan profitabilitas yang diukur dengan ROE.

Hasil dalam regresi (1) mengungkapkan hubungan positif yang signifikan antara SDA dan profitabilitas. Hal ini menunjukkan bahwa utang jangka pendek cenderung lebih murah, dan karena itu meningkatkan utang jangka pendek dengan suku bunga yang relatif rendah akan menyebabkan peningkatan tingkat keuntungan. Regresi (2) menunjukkan hubungan negatif yang signifikan antara LDA dan profitabilitas. Ini menyiratkan bahwa peningkatan posisi utang jangka panjang dikaitkan dengan penurunan profitabilitas. Hal ini dijelaskan oleh fakta bahwa utang jangka panjang relatif lebih mahal, dan karena itu mempekerjakan proporsi tinggi dari mereka dapat menyebabkan profitabilitas rendah. Hasilnya mendukung temuan sebelumnya oleh Miller (1977), Fama dan French (1998), Graham (2000) dan Booth et al. (2001). Hasil dari regresi (3) menunjukkan hubungan positif yang signifikan antara DA dan profitabilitas. Koefisien regresi positif yang signifikan untuk total utang menyiratkan bahwa peningkatan posisi utang dikaitkan dengan peningkatan profitabilitas: dengan demikian, semakin tinggi utang, semakin tinggi profitabilitasnya. Sekali lagi, ini menunjukkan bahwa perusahaan-perusahaan profit lebih bergantung pada utang sebagai opsi pendanaan utama mereka. Ini mendukung temuan Hadlock dan James (2002), Petersen dan Rajan (1994) dan Roden dan Lewellen (1995) bahwa perusahaan-perusahaan profit menggunakan lebih banyak utang. 


\section{KESIMPULAN}

Penelitian ini dilakukan dengan tujuan untuk memperoleh bukti empiris apakah struktur modal berpengaruh signifikan positif terhadap perofitabilitas. Populasi yang digunakan dalam penelitian ini adalah perusahaan sektor konsumsi yang terdaftar di Bursa Efek Indonesia (BEI) sesuai dengan minat penelitian. Data diambil dari laporan keuangan populasi periode 2014-2016, didasarkan Public Hearing yang diselenggarakan oleh Dewan Standar Akuntansi Keuangan (DSAK) - Ikatan Akuntan Indonesia (IAI) tahun 2010 di Jakarta yang menyatakan mengenai konvergensi IFRS tahun 2012. Pemilihan sampel dilakukan dengan menggunakan metode purposive sampling, yaitu pengumpulan sampel berdasarkan pertimbangan kriteriakriteria tertentu.

Terdapat 87 data dalam tiga tahun yang telah memenuhi kriteria dan dapat dijadikan sampel penelitian. Model yang digunakan untuk menguji hipotesis adalah pengujian model SPSS. Sebelum dilakukan pengujian hipotesis, maka terlebih dahulu perlu dilakukan statistik deskriptif dan uji asumsi klasik.

Berdasarkan hasil analisis data dan pengujian hipotesis yang telah dilakukan pada bab empat, maka kesimpulan dari hasil penelitian ini adalah:

1. Struktur modal (SDA) berpengaruh signifikan positif terhadap profitabiltas perusahaan. Hal ini disebabkan karena perusahaan yang meningkatkan hutang jangka pendek dengan biaya yang relatif rendah akan menyebabkan peningkatan tingkat laba.

2. Struktur modal (LDA) berpengaruh signifikan negatif terhadap profitabilitas perusahaan. Hal ini dijelaskan oleh fakta bahwa utang jangka panjang relatif lebih mahal, dan karena itu mengunakan proporsi tinggi dari mereka dapat menyebabkan profitabilitas rendah.

3. Struktur modal (DA) berpengaruh seignifikan positif terhadap profitabilitas perusahaan. Hasil penelitian mendukung hasil penelitian dari Abor (2005) yang menunjukan adanya pengaruh positif signifikan dari total utang menyiratkan bahwa peningkatan posisi utang dikaitkan dengan peningkatan profitabilitas: dengan demikian, semakin tinggi utang, semakin tinggi profitabilitasnya. Perusahaan-perusahaan profit lebih bergantung pada utang sebagai opsi pendanaan utama mereka. Ini mendukung temuan Hadlock dan James (2002), Petersen dan Rajan (1994) dan Roden dan Lewellen (1995) bahwa perusahaanperusahaan profit menggunakan lebih banyak utang (Abor, 1995).

Penelitian ini mengandung beberapa keterbatasan diantaranya penelitian hanya membuktikan keterkaitan pengaruh struktur modal terhadap profitabilitas perusahaan dengan variabel kontrol ukuran perusahaan dan pertumbuhan penjualan. Struktur modal dibagi menjadi 3 bagian yaitu model hutang jangka pendek (SDA), model hutang jangka panjang (LDA) dan model total hutang (DA). Selain itu, sampel penelitian ini adalah perusahaan sektor konsumsi. Perusahaan sektor konsumsi dipilih sesuai dengan minat penelitian. Oleh karena itu, cakupan penelitian hanya sebatas pada perusahaaan sektor konsumsi.

\section{DAFTAR PUSTAKA}

Abor, Joshua. (2005). The Effect of Capital Structure on Profitability: an empirical analysis of listed firms in Ghana. The Journal of Risk Finance, 6 (5), 438-445.

Abrar dan Javaid. (2016). The Impact of Capital Structure on the Profitability of Microfinance Institutions. South Asian Journal of Management Sciences , 10 (1), 21 37.

Brigham, Eugene F. dan Joel F. Houston.(2004). Fundamentals of Financial Management. Tenth Edition. Mason: Thomson South-Western. 
Chisti, Ali, dan Sangmi (2013). Impact Of Capital Structure On Profitabiliy Of Listed Companies (Evidence from India). The USV Annals Of Economics and Public Administration, 13 1(17).

Firnanti, Friska. (2011). Faktor-Faktor Yang Mempengaruhi Struktur Modal Perusahaan Manufaktur di Bursa Efek Indonesia. Jurnal Bisnis dan Akuntansi. 13. (2). 119-128.

Frank dan Goyal. (2009). Capital Structure Decisions: Which Factors Are Reliably Important. Financial Management Journal.

Ghozali, Imam. (2008). Structural Equation Modeling Metode Alternatif dengan Partial Least Square (PLS). Edisi 2. Semarang: Badan Penerbit Universitas Diponegoro. (2012). Aplikasi Analisis Multivariate dengan program IBM SPSS 20. Edisi 6. Semarang: Badan Penerbit Universitas Diponegoro.

Ghozali, Imam dan Latan, Hengky. (2015). Partial Least Squares Konsep, Teknik, dan Aplikasi menggunakan Program SmartPLS 3.0. Edisi 2. Semarang: Badan Penerbit Universitas Diponegoro.

Gill, Biger, dan Mathur (2011). The Effect of Capital Structure on Profitability: Evidence from the United States. International Journal of Management, 28 (4).

Hussain (2015). Does Capital Structure Effects Profitability of The Firms (Evidence from Firms Listed at KSE 100 Index). Research Journal of Finance and Accounting, 6 (5).

Lasher, William R. (2011). Financial Management: A Practical Approach. Sixth Edition. New York: South-Western Cengage Learning.

Melani, Agustina. (2017). Bank Besar Cetak Laba Positif Pada Kuartal I 2017 from http://bisnis.liputan6.com/read/2938592/bank-besar-cetak-laba-positif-pada-kuartal-i2017.

Putra dan Badjra. (2015). Pengaruh Leverage, Pertumbuhan Penjualan dan Ukuran Perusahaan Terhadap Profitabilitas. E-Jurnal Manajemen Unud, 4 (7), 2052-2067.

Sartono, Agus. (2001). Manajemen Keuangan: Teori dan Aplikasi. Edisi Keempat. Yogyakarta: BPFE Yogyakarta.

Sjahrial, Dermawan. (2010). Manajemen Keuangan. Edisi 4. Jakarta:Mitra Wacana Media.

Shubita dan Maroof. (2012). The Relationship between Capital Structure and Profitability. International Journal of Business and Social Science, 3 (16).

Yegon, dkk. (2014). The Effects of Capital Structure on Firm's Profitability: Evidence from Kenya's Banking Sector. Research Journal of Finance and Accounting, 5 (9).

Yinka dan Oluwadetan (2015). Capital Structure and Profitability: A Critical Analysis of Quoted Manufacturing Companies in Nigeria. American Journal of Economics, Finance and Management, 1 (5), 369-376.

http://www.idx.co.id/ . Terakhir diakses pada 29 Mei 2017 pukul 20.00 WIB 


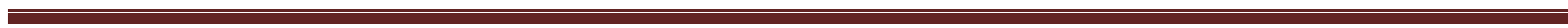
$\cdot$ 